\title{
Die idioom van die Nederduitsch \\ Hervormde Kerk - 'n Teologiese vraag
}

\author{
J H Koekemoer
}

Universiteit van Pretoria

\begin{abstract}
The idiom of the Nederduitsch Hervormde Kerk - A theological question

This article focuses on the theological thinking in the Nederduitsch Hervormde Kerk. The way in which the doing of theology in the Nederduitsch Hervormde Kerk take place has been influenced by ethical theology, dialectical theology and existential theology. In this context theology cannot be a final conclusion, but rather a new exchange of views about the question of proper theology, namely the knowledge of God and the service of God among and for humankind.
\end{abstract}

\section{INLEIDENIDE OPMERKINGS}

'n Lesing met bogenoemde titel, wat tydens die Hervormde Teologiese Vereniging se kongres van 1992 deur skrywer hiervan gehou is, het aanleiding gegee tot verdere nadenke oor die saak. By daardie geleentheid reeds was die gevolgtrekking waartoe geraak is dat 'n poging om na 'n eie idioom van teologiese refleksie te soek, nie so' 'n maklike en vanselfsprekende aangeleentheid is nie. Veral as in gedagte gehou word dat Oberholzer (1993:870-886) in 'n voordrag oor die teologiese eie-aardigheid van die Nederduitsch Hervormde Kerk wat hy voor die predikantevergadering gedurende dieselfde jaar gehou het, aantoon dat die teologiese posisie van die Nederduitsch Hervormde Kerk by voorkeur as Bybels-Reformatories aangedui kan word, alhoewel dadelik bygevoeg moet word dat die lede van die teologiese fakulteit elkeen op sy eie wyse aan hierdie begrip inhoud probeer gee het. Juis daarom sou dit ver- 
standig wees om weer eens na die vraag te kyk. In so 'n nuwe soeke na die formulering van 'n eie teologiese idioom kan dan immers iets van die menslike onvermoë om die onsêbare te sê, na vore tree.

Oberholzer (1993:879-880) vra ook na 'n herbesinning oor die saak omdat hy oordeel dat die saak na die tweede wêreldoorlog 'en veral van die sestigs af' baie gekompliseerd geraak het. Hy skryf dit daaraan toe dat die handelinge van die kerk en die werk van sy teoloë, op 'n ander wyse reaktief geword het. Aanleidende oorsake hiervoor was 'die bedreiging van 'n nuwe teologie wat in 'n verskeidenheid mutasies vorm geneem het: ekumenies, sosiaal, sonder eskatologie of min daarvan, gereed om werktuig te wees van die politieke, sosiale en ekonomiese aspirasies van almal wat hulleself as arm en veronreg beskou het.

Hy oordeel dat hier in 'n ekumeniese kleed 'n burgerlike godsdiens gestalte aangeneem het. Die probleem wat hy ten opsigte van die Nederduitsch Hervormde Kerk identifiseer, is dat die kerk en sy teologie hierop geantwoord het 'met 'n reglynige weerstand en 'n verbete vashou aan tradisionele posisies' (Oberholzer 1993:880). By party van die teoloë in die Nederduitsch Hervormde Kerk merk hy dan 'n ander burgerlike godsdiens, en vra die vraag: Die antwoord op die ekumeniese burgerlike teologie lê sekerlik nie in 'n ander burgerlike teologie nie' (Oberholzer 1993:880).

\section{OP SOEK NA 'N EIE TEOLOGIESE IDIOOM}

Dat die vraag na 'n eie teologiese idioom binne die Nederduitsch Hervormde Kerk nog steeds aktueel is, en da die kerk steeds daarmee worstel en die antwoorde uit die verlede nie as finale antwoorde beskou nie, word in debatte wat in Die Henormer vanaf 1992 tot 1994 gevoer is, onderstreep.

In 'n brief in Die Henormer spreek P B Boshoff (1990:6) sy bekommernis daarocl uit dat oorgeërfde goedere dalk maar net oorgeërf kan bly en nooit eie goed kan word nie. Hoewel hy erken dat erfenis 'n tydskategorie is, pleit hy daarvoor dat dit dalk eerder in ruimtelike terme beskryf moet word. Hy oordeel so omdat dit volgens hom minder pretensieus is om jou plek as jou tyd te ken. Toegepas op die vraag na 'n eie teologiese idioom, moet dalk erns gemaak word met die opmerking dat die begrip 'Hervormd' ' $n$ wyer begrip as 'Gereformeerd' is. Dit is so omdat 'Hervormd' volgens sy oordeel ook 'Luthers' insluit, terwyl 'Gereformeerd' dit uitsluit. As die interpretasie van Boshoff korrek is, is hy ewe-eens reg as hy beweer dat Hervormde teologie om hierdie rede deur 'n 'ontdekkende nederigheid gelei behoort te word'. 
Met hierdie 'ontdekkende nederigheid' sal daar nou gekyk word na die uitsprake in Die Hervormer met betrekking tot 'n eie teologiese idioom en dan sal met dieselfde nederigheid in gedagte, gepoog word om enkele teologiese aspekte na vore te bring wat in die soeke na 'n Hervormde teologiese idioom van betekenis kan wees.

In 'n redaksionele artikel Die Hervormer (1992:4) word geoordeel dat die vraag na 'n eie Hervormde teologiese idioom om verskillende redes 'n moeilike vraag is om te beantwoord, veral vanweë die min teologiese publikasies in die rigting. Die skrywer stel egter verder:

Hoewel ons 'n baie sterk inslag van die dialektiese teologie het, laat ons ons nie in 'n hoek druk nie - nie in 'n dialektiese of neo-calvinistiese of ' $n$ metodistiese of watter hoek ookal nie. Hoewel ons BybelsReformatories konserwatief is, onsself as Afrikaanse volkskerk beskou en spore van 'n konfessionele en 'n etiese teologie toon, het ons nog altyd ons teoloë die vryheid gegun om binne die grense van ons soort konserwatisme vry te beweeg.

Wat met hierdie 'konserwatisme' bedoel word, word egter nie uitgespel nie, behalwe dat gestel word dat hier met 'n saak te doen gekry word 'wat soos kwiksilwer is - dit is werklik daar, dit is gewigtig, maar kan nie raakgevat word nie'. Tog moet die afleiding gemaak word dat dit hier gaan om 'n konserwatiewe teologie wat binne die konteks van sosio-politteke omstandighede baie kontekstueel van aard was. 'n Bepaalde werklikheidsverstaan binne die tyd-ruimtelike konteks in die Suid-Afrikaanse situasie het bepaald hierin 'n rol gespeel. Onder die opskrif 'Aktuele kerklike en teologiese kwessies van ons tyd' (Die Hervormer 1993:5) word die ernstige vraag geopper of die stryd om ons eie kerklike etos en teologiese idioom te behou, nie die kerk se apostolaat in die wiele ry nie. Nieteenstaande dié vraag, word tog geoordeel dat ongeag hoeveel nuanseverskille oor die saak mag bestaan, daar $\log$ 'n duidelike Hervormde teologiese idioom en etos onderskei kan word.

Die idioom wat so onderskei word, word onderskei van 'blote tradisie beheptheid en 'n klouery aan uiterlike vorme wat die ware en noodsaaklike kerklike, teologiese en liturgiese vernuwing in die weg staan' (Die Hervormer 1992:5).

Daar word geoordeel (Die Henormer 1992:5) dat beide kerklike etos en idioom voortdurend aan die Woord getoets moet word, en as dit met die nodige eerlikheid en kritiese ingesteldheid gedoen word, behoort dit nooit die apostolaat van die kerk in die wiele te ry nie. Miskien is dit juis hierdie eerlike en kritiese ingesteldheid van teoloë van die kerk wat binne 'n nuwe konteks en in die lig van die progressie in die teologie, die vraag na 'n eie teologiese idioom opnuut laat verlewendig. Ons leef immers in 'n wèreld wat voortdurend aan verandering onderworpe is. 'Of 'n mens 
nou met hierdie hedendaagse beskouïngs saamstem of nie, kan jy vandag skaars anders as om hulle grondslag te erken. "n Westerse kultuur wat vloeibaarder en oper geword het, wat wegskram van absolute waarhede' (Du Toit, in De Kat 1993:74). 'n Mens sou dit ook anders kan sê:

Ons is op die oomblik in 'n oorgangstydperk, 'n maalstroom van verwarring, en die antwoorde het nog nie uitgekristaliseer nie. Soos aan die begin van die Renaissance staan ons op die drumpel van kulturele verandering in die hele Westerse wêreld, en dit het ten seerste implikasies vir die godsdiens.

(Loader, in De Kat 1993:75)

Wanneer die opmerking van David Tracy (1981:4) ernstig geneem word, naamlik dat daar tussen drie tipes kontekste of gehore waaraan teologie moet voldoen, onderskei moet word, kan die maalstroom van verandering op die sosio-politieke terrein in Suid-Afrika ook nie buite rekening gelaat word nie. Dit onderstreep net die feit dat die wêreld waarin ons leef en teologie bedryf, verskil van die een waarin die Bybel geskryf is of die wèreld waarin onder andere Augustinus, Luther en Calvyn hulle teologiese interpretasies van die Christelike geloof geformuleer het. Wanneer Van Aarde (1993:5) 'n antwoord probeer kry op die vraag waarom die evangelie dan die objek van so 'n teologiese besinning geword het en waarom daar nie in dié opsig gebly kan word by dit wat in 'n kinderlike gemoed aanvaarbaar is nie, gee hy ' $n$ antwoord wat tegelyk verklaar waarom die vraag na 'n teologiese idioom so ' $n$ intense diskussie veroorsaak:

Dit is die ingewikkelde konteks waarbinne die Jesus-gebeure grondgevat het; dit is die besondere taal waarin en die meersinnige woorde waarmee dit uitgedruk is; dit is die eiesoortige wêreldbeskouing in terme waarmee dit verduidelik is; dit is die vreemde godsdienste waarmee dit vergelyk is; dit is die dogmas wat gebruik is om dit te onderbou; die filosofie, die kultuur, samelewing, politiek en ekonomie waarin die evangelie en die onderbouende dogmas ingebed is en wat so totaal anders is as die waaraan ons vandag gewoond is. Dit is met ander woorde die afstand tussen antiek en modem, tussen die betekenis van die evangelie destyds en die betekenis van die evangelie vandug.

Hierby moet nog gevoeg word dat die teologie probeer om oor God te praat. In hierdie poging word 'teorieë ontwerp en modelle ingespan' (Van Aarde 1993:5) om dit sinvol te kan doen. Die verwoording wat hieruit voortvloei, kan egter nie met God gelyk gestel word nie. Wie erken en bely dat God God is, sal ook verstaan dat 
Hy volkome vry is en dat Hy Homself nooit as gevangene aan ons spreke oor Hom oorgee nie. Hierdie wete behoort tot versigtigheid te maan en die besef te laat groei dat menslike formuleringe, al is dit ook pogings om iets oor God te sê, nooit iets anders as 'n gebrekkige menslike poging is nie. God val derhalwe nooit saam met en kan nie gelyk gestel word aan die gesprek oor Hom nie. Miskien is dit wat Van Niftrik (1948:17) oor die teologie van Karl Barth gesê het, hier van betekenis:

Hy het die kerk en teologie opnuut geleer om God te sê. God in die volle sin van die Woord. God: nie as projeksie van ons ideale - nie as voorwerp of produk van ons religieuse ontroering - nie as waarborg van ons sedelikheid nie - God: nie die starre God van die filosowe, 'n idee, 'n abstraksie nie - Nee, God, die lewende God, die God van die Bybel, Vader, Seun en Heilige Gees. God wat God bly ook wanneer Hy in relasie tree met die mens en die wêreld.

Wanneer kerk en teologie in sy gesprek oor God hiervan iets tereg wil laat kom, sal begryp word dat 'n kerklike idioom ook nie te star en bestendig kan wees nie. lets van die beweeglikheid wat teologiese spreke kenmerk, behoort hier aan die orde te kom. In 'n artikel getiteld 'Mites, metafore en teologie' verwoord Van Aarde $(1993 \mathrm{~b} 5,6 ; 1994: 5,6)$ iets van hierdie waarheid wat so eie aan die teologie behoort te wees. Die beweging in hierdie gesprek tree daaruit na vore dat so' $n$ gesprek oor God tegelyk gesprek met God sal wees (O1t 1974:79) en dat die moderne mens wat tuis is in die wêreld van rekenaars en mikro-elektronika, steeds hierdeur so eksistensieel aangespreek sal voel (Van Aarde 1994:6) dat hy in 'n ontmoetingsgebeure die Here sal hoor.

So kom regte denke en spreke oor God derhalwe voort uit 'n ontmoeting met God, terwyl dit tegelyk weer gerig is op 'n ontmoeting met God (Berkhoff 1973:32). Teologiese denke en spreke is derhalwe eindige spreke met sy eie begrensing, en juis daarom behoort reglynige uitsprake oor God en 'n te strakke sisteemdenke, vermy te word. In die teologiebeoefening in die Nederduitsch Hervormde Kerk was daar altyd 'n bepaalde huiwering ten opsigte van te vasstaande sisteemdenke. Oberholzer (1993:874) voer vir so 'n argument soos hierdie 'n goeie bewysvoering uit die geskiedenis aan. Vir die argument hier kan volstaan word met die uitspraak van $M$ J Goddefroy (1889:11; ook by Oberholzer 1993:874): 'Die suiwere leer, daar kom dit op aan! Maar die suiwere leer is nooit ofte nimmer by llervormers die leer van hulle vadere, of die konsilies nie; maar altyd en alleen wat die Heilige Skrifte leer'.

Dit is dalk juis dit wat Boshoff (1990:6) laat vermaan dat die eie teologiese erfenis ondergrawe word deur 'selfverklaarde Groot Afrikaners onder predikante' wat nou roem dat hulle die lig gesien het, en 'ongetwyfeld van die kerkvolk verwag om hulle as Afrikaners te bewonder terwyl bewondering nog nooit ' $n$ aangemoedig- 
de deel van ons kerklike lewe was nie. Hy maan uit die agtergrond van 'n eie teologiese tradisie tereg tot meer beskeidenheid in lewe en 'n 'teologiese arbeid wat deur ontdekkende nederigheid gelei behoort te word'.

In Hervormde teologiebeoefening was daar altyd 'n terughoudenheid om van 'Hervormde' teologie te praat, die begrip Bybels-Reformatoriese teologie is telkens verkies (Oberholzer 1993:880). Tegelyk is daar gewerk met die vooronderstelling dat teologie in diens van die kerklike verkondiging is. En omdat die belydenisskrifte in dié opsig gesien is as 'n regulerende wegwyser ter wille van die suiwerheid van die verkondiging eerder as 'n gepatenteerde verstaan van die Skrif waarvan nooit afgewyk mag word nie, is daar dan ook van belydende kerk in plaas van belydenis-kerk gepraat. Hierdeur is iets onder woorde gebring van die beweeglikheid van die Woordgebeure in die teologie. Die vraag bly immers steeds: Hoe is dit moontlik dat die Woord van God uit die mond van 'n mens gehoor kan word? Die waarborg dat dit moontlik is, tree nie in vaste sisteme na vore nie. Dit word nooit 'n vanselfsprekende saak nie, dit vind alleen in 'n gebeure plaas, wanneer God die Heilige Gees, God self, dit moontlik maak. Die ontoereikenheid van teologiese taal tree nêrens duideliker op die voorgrond as juis hier nie. En alhoewel Bonhoeffer (1982:8) gestel het dat 'n gesprek oor God altyd met swye begin, en teologiese taal ontoereikend in die gesprek oor God is, kan daar tog nie in swye geëindig word nie. Die gesprek our God en die mense gaan immers voort (Ott 1981:88). In hierdie gesprek verander die voorwaardes waaronder uitsprake gemaak word, voortdurend. 'Die mens en sy situasie verander voortdurend en daarom verander die duiding van die openbaring telkens, want dit kom telkens in 'n nuwe situasie ter sprake' (Koekemoer 1992:327).

In sy worsteling om in so 'n situasie aan die teologiese gesprek deel te neem, en so deel te neem dat dit ten dienste van die kerklike verkondiging kan wees, was daar binne die teologiese gesprek in die Hervormde teologie altyd 'n afgrensing na twee kante toe aanwesig. Hierdie afgrensing het nooit daarop neergekom dat daar 'n midde-posisie tussen die twee kante gekies is nie. Die eerste waarteen die afgrensing plaasgevind het, was die teologiese rigting wat in die gereformeerde ortodoksie gevolg is. Volgens Van Niftrik (1948) word op dié wyse van teologiebeoefening die objektiwiteit van die openbaring van God sterk beklemtoon. Dogmatiese waarhede word dan in hulle objektiewe massiwiteit beklemtoon en ten toon gestel. Die teologiese metode is derhalwe een waarin waarhede uitgestal word sodat 'n relasie daarmee gesoek kan word. Die objektiewe waarheid word dus teenoor die hoorder gestel met die eis: Jy moet dit glo. 
Die tweede moontlikheid is die weg van die mistiek, wat Barth die kritiese metode noem. Hier kry die tweede woord, die subjektiewe weer al die klem (Van Zyl 1993:5).

Binne die Hervormde teologie het die karakter van die derde opsie dan sy gestalte gekry. Loader (1989:431-436) beskryf die karakter van die derde opsie as 'eties'. Hy verstaan 'eties' dan so dat dit nie 'sedelik' beteken nie, maar dat die 'wese van die waarheid' vir dié teologie in die sentrum van belangstelling staan (Loader 1987:48). Hieroor stel hy:

Die Hervormde tradisie in ons land neem al lank 'n 'derde opsie' in: aan die een kant word ons begrens deur die gereformeerde ortodoksie waarmee ons onsself nooit kan vereenselwig nie en aan die ander kant word die grens getrek deur die verhemente ontkenning van die beskuldiging dat die Hervormde teologie 'liberaal' sou wees, soos dikwels uit gereformeerde oord beweer word'.

(Loader 1987:48)

Hierdie derde opsie dat ons nóg 'ortodoks gereformeerd' nóg 'liberaal' is, bring die diepgaande invloed wat die Hervormde teologie in Suid-Afrika van die Nederlandse 'derde opsie' ondergaan het, sterk na vore (Loader 1987:48).

Volgens Loader (1987:48) is hierdie siening, waar die wese (ethos) van die waarheid in die sentrum van belangstelling staan, deur Daniel Chantepie de la Saussye onder woorde gebring met die voorstelling van die etiese karakter van die waarheid. Dit het vir hom beteken dat die wese van die waarheid nie objektiveerbaar en rasionaliseerbaar is nie, maar dat die mens wel daarmee in aanraking kan kom. Die waarheid kan nie in die leer vasgevat word nie, want dit transendeer alle konsepte en proposisies wat gebruik word om dit uit te dra. Daarteenoor kan die mens wel met die waarheid in aanraking kom en daarmee gekonfronteer word.

'As die mens God nie kan deurgrond nie, dan kan hy God nog ontmoet' (Loader 1987:49). Loader (1989:412-443) beredeneer ook die invloed wat daar van die etiese teologie op die teologie van die Nederduitsch Hervormde Kerk uitgegaan het. Ook Van Aarde (1992:139-158) gee hieraan aandag en Koekemoer (1992:315327) verwys daarna.

Alhoewel Pont (1994:106) ook redeneer dat Hervormde teologie hom afgegrens het teen bepaalde strominge wat hy identifiseer as die juridies-konfessionele rigting aan die een kant en die subjektiewe teologie van die Metodisme aan die ander kant, ontken hy dat daar dan gekies is vir 'n derde opsie, soos deur Loader (1989:412-437) beredeneer. 
Alhoewel Pont toegee dat daar wel lede van die Fakulteit Teologie (Afd A) aan die Universiteit van Pretoria was wat in die rigting van die etiese teologie geneig het, is hy nie daarvan oortuig dat die etiese rigting die teologiese gerigtheid van die Fakulteit was nie. Hy oordeel meer in die rigting van 'n konfessionele teologie wat met die koms van Wolmarans na die Fakulteit toe, 'n bepaalde invloed van die dialektiese teologie ondergaan het (Pont 1994:107).

Met dit in gedagte, is dit nou interessant om daarop te let dat Mans (1967:494) in sy proefskrif oor P J Müller as dogmatikus, Müller as ' $n$ 'etiese ortodokse' en 'etiese regse' tipeer. Hy voeg egter hieraan 'n sienswyse toe wat 'n bepaalde ander perspektief in Hervormde teologiebeoefening na vore roep en wat in 'n poging om 'n Hervormde teologiese idioom te identifiseer, nie geignoreer kan word nie. Alhoewel hy oordeel dat Müller wel tot die etiese rigting behoort het, noem hy hom ook 'n 'konfessionele dogmatikus'.

Dit is duidelik dat ons hier met 'n getemperde konfessionele benadering te doen het. Die tempering wat vanuit die etiese teologie na vore getree het, het die gevaar van 'n verval in konfessionalisme teengewerk. In dié teologie gaan dit om die verhouding God-mens teologies te deurdink met die erkenning daarvan dat die mens ook wel binne 'n geloofs of konfessionele tradisie leef waarin daar telkens weer en weer probeer is om God te sê.

Haitjema (1948:7) praat in dié verband van 'n eksistensieel-teologiese en dialekties-paradoksale benadering. Ook Van Niftrik (1953:19) verwoord hier iets van as hy stel dat dogmatiese denke eksistensieel wil wees. Die objektiewe waarheid is 'n waarheid wat my aangaan. Daarom is elke dogmatiese uitspraak 'n waarheid ad hominem. Terwyl die Kleine Dogmatiek van G C van Niftrik na die boek van P J Müller, vir 'n hele aantal jare as die standaard dogmatiekhandboek in die Fakulteit Teologie (Afd A) gebruik is, is dit vanselfsprekend dat dié wyse van teologiebeoefening in die Fakulteit en in die Nederduitsch Hervormde Kerk inslag sou vind. Dit lyk immers na 'n logiese afleiding dat die invloed van die etiese teologie, die pad na die dialektiese teologie en die eksistensiële benadering in die teologie oopgemaak het. Dit gaan hier om 'n verhouding met die waarheid eerder as om objektiewe waarhede wat geformuleer word.

In Hervormde teologiebeoefening het die saak uitdrukking gevind in onder andere die volgende formuleringe wat dikwels in geskrifte opduik.

* Openbaring word gestel teenoor geopenbaarheid. Waar openbaring 'n aktiewe daad van God is, is geopenbaarheid 'n statiese gegewenheid.

- Wanneer oor God gepraat word, is daar tegelyk van openbaring en verberging sprake.

- Die absolute kwalitatiewe verskil tussen Skepper en skepsel. 
* Die soekende nood van die mens waarmee hy na die Woord van God gaan. 'n Soekende nood wat nooit 'n afgehandelde saak word nie. Hierdie soekende worsteling word altyd weer opnuut onderneem in die vaste vertroue dat God sy belofte dat Hy Hom deur sy Woord aan ons sal openbaar, waar sal maak.

- God as die Gansandere oor wie daar nooit reglynige uitsprake gemaak kan word nie. Ook wanneer God Hom aan ons openbaar, bly Hy steeds God en kry ons nooit mag oor Hom nie. Ook in sy openbaring bly Hy die groot Verborgene (Deus Absconditus), oor wie ons nooit reglynig (wat dieselfde is as selfgenoegsaam en vanselfsprekend) kan praat nie. maar van wie ons altyd dialekties probeer praat.

- Die gees van die ortodoksie, modernisme en liberalisme is vir die kerk 'n dodelike siekte.

- Geloofstaal is simboliese taal. Dit het die kerk deur worsteling uitgevind.

Indien, in die lig hiervan, van 'n Hervormde teologiese idioom gepraat moet word, sal dus teen verstarring gewaarsku moet word, sal sisteemdenke vermy moet word en sal daar ruimte moet kom vir die vlugtigheid van die woord. Daar sal altyd opnuut geleer moet word om God te sê en in hierdie proses sal op die skouers van vorige geslagte gestaan word sonder om teologiese uitsprake van die verlede as absolute waarhede te beskou. Kerk en teologie is nie veronderstel om ander dinge oor God te sê nie, maar om die dinge voortdurend anders te sề (Van Niftrik 1948). Terwyl kerk en teologie met hierdie poging besig is, is dit 'n futiele oefening om tussen die pole van objektivisme en subjektivisme rondgeslinger te word. Die oordeel van Loader (1987:48) dat in Hervormde teologie dit in die saak om 'n derde opsie gegaan het, lyk na 'n korrekte beskouing.

Binne Hervormde teologie het die uitoefening van dié opsie aanvanklik in die idioom van die etiese teologie inslag gevind. Hiermee saam was daar tegelyk sprake van 'n getemperde konfessionele teologie. Met die loop van die tyd het die dialektiese teologie en die eksistensiële teologie ook hulle invloed binne Hervormde teologiebeoefening laat geld. In 'n sekere sin is dit makliker om te sè wat Hervormde teologie nie is nie, as om dit te omskryf. Die rede hiervoor is heelwaarskynlik dat daar nooit die bedoeling was om 'n 'vaste, omlynde skoolse teologie te beoefen nie (Pont 1994:106). Die wyse waarop Van Zyl (1993a; 1993b; 1993c; 1993d) en Van Aarde (1993a; 1993b; 1994) aan die teologiese gesprek in Die Henormer deelgeneem het, bevestig so 'n stelling. Die teologie is 'n ernstige poging om oor God te praat op ' $n$ ander wyse as bloot om met 'n harde stem oor die mens te praat (Engelbrecht 1966:68). Natuurlik word die betrokkenheid van die mens by die feit dat God Hom aan die mens openbaar, nie ontken nie. Daarom kan die mens ook nooit as 'n toeskouer oor die dinge praat nie, maar alleen as iemand wat 
eksistensieel deur God gegryp is. Die deurdenking van hierdie vasgrype, vind binne die kerk gewoonlik sy gestalte in 'n belydenisformule. Die veronderstelling is dan dat hierdie belydenisformule nie in 'n starre onveranderlike geopenbaarde dogma sal verander nie. Want as dit gebeur, is geloof nie meer 'n lewe voor die aangesig van die lewende God nie ('n relasie dus), maar word dit die nakom van dogmas (geloofreëls) as objektiewe gegewenhede wat deur die kerk neergelê is. Juis omdat die dogma die wyse is waarop die Woord van God in die geloof in 'n bepaalde konkrete situasie neerslag gevind het, kan dit nie tot iets eiemagtigs teenoor die Woord van God verhard nie. Dit moet altyd 'n onafsluitbare openheid na vore behou. Dit kan ook nooit tot die vanselfsprekende eiendom van die kerk gereken word nie, maar dit moet altyd denkend in en vir die geloof bruikbaar gemaak word. Dus nie 'n starre idioom nie, maar 'n lewendige denkproses in die teologie wat daarom ook steeds sy voorlopigheid behou.

'n Gesaghebbende teologiese tradisie moet dus altyd weer opnuut in 'n nuwe situasie invertaal word omdat die tradisie nie oorspronklik op die nuwe situasie betrekking gehad het nie (Weber 1955:86).

Die hantering van die triniteitsdogma uit die vierde eeu kan as voorbeeld gebruik word om bogenoemde argument te bevestig. In wese word in die dogma niks anders gesê as in die belydenisformule 'Jesus is die Here', nie. Hierdie ou belydenis word nie eens verstewig nie. Al wat gebeur, is dat hierdie ou belydenis binne ' $n$ bepaalde taalraamwerk teen.'n kettery en die bedreiging van die kerk van buite, nuut gesê word.

Die kerk en teologie is geroepe om die gesprek oor God en die mense aanhoudend te verwoord. Die enigste motief agter so 'n voortgaande spreke behoon te wees om die regte belydenis na vore te bring. Hier is hoegenaamd nie sprake van 'n nuwe ontdekking nie, maar eerder van 'n ou belydenis wat in 'n nuwe situasie coram Deo anders en daarom nuut gesê word. Die kerk is immers geroepe om onder nuwe omstandighede, binne sy eie geloofstradisie, die paradoks van die Woord wat mens geword het, opnuut te deurdink en te bely. So 'n nuwe belydenis maak die oue nie tot niet nie, maar sluit dit in. Daarom het die konfessies van die Reformasie dan ook die ou simbole van die kerk bly erken. So bewaar die kerk nie alleen sy eie tradisie nie, maar keer hy tegelyk dat dit versteen en tot objektiewe waarhede vermink word (Koekemoer 1991:19).

In ons soeke na 'n sogenoemde Hervormde teologiese idioom, moet die uitspraak van Karl Barth oor sy eie teologiebeoefening, soos Godsey (1966:4) dit weergee, ernstig geneem word: 
Die engele lag vir Karl Barth. Hulle lag vir hom omdat hy probeer om die waarheid oor God in 'n Dogmatiekboek saam te vat. Hulle lag vir die feit dat hy volume na volume produseer, die een meer omvangryk as die ander. Hulle lag vir hom en hulle lag vir al die mense wat so baie oor hom skryf, in plaas daarvan om oor die dinge te skryf waaroor hy probeer skryf (my vertaling).

Toegepas op die soeke na 'n spesifiek Hervormde teologiese idioom, moet ons daarteen waak dat die idioom nie belangriker word as dit wat die idioom probeer verwoord nie. Die krampagtige vasklem aan 'n eie selfstandige idioom kan die idioom maklik laat verstar. Dan word die wyse waarop die waarheid op 'n bepaalde stadium in die geskiedenis verwoord is, maklik belangriker as die waarheid self. Daarom die pleidooi vir beweging. Dit is die beweging wat ook binne die Etiese teologie, die dialektiese teologie en in 'n pleidooi vir die akkomodering van nuwe insigte in die gesprek oor God, bepleit word (Van Aarde 1993:5). Die taak van die teologie is immers nie om idiome in stand te hou nie, maar om oor God te praat. In hierdie gesprek word steeds weer gesoek na die moontlikheid met die minste foute wat die gesprek die beste kan dien.

Natuurlik beteken dié uitspraak nie dat die kerk geen eie geloofstradisie het nie. Die gevaar van verstarring van 'n geloofstradisie word alleen beklemtoon. Verder word 'n pleidooi vir 'n openheid in kerk en teologie, wat met liefde vir die eie ook die eie krities kan beoordeel, gelewer. 'n Idioom kan nooit as 'n gegewenheid beskou word wat nie krities bevra kan word nie.

Juis omdat vertolking aksentverskuiwing meebring, was en is die gevaar van misvorming van die openbaring altyd aanwesig. Wanneer dit gebeur, word aan die idees en ideale van die situasie beantwoord in plaas daarvan dat daarop ' $n$ antwoord gegee word. Dan word die openbaring geblokkeer in plaas daarvan dat deurgang daaraan verleen word. Aan die gevaar is ons voortdurend blootgestel. Hoe kan dit ook anders: Die openbaring is immers na sy inhoud in teëspraak met ons aspirasies, ook ons godsdienstige aspirasies. En die mens het eenmaal die vermoë om elke geleentheid te gebruik om sy eie aspirasies bevestig te kry. Baie tradisies is valse tradisies, 'n weerspreking van die werk van die Gees. Wie dit begryp, begryp tegelyk die vraag of die Christusgebeure ooit in hierdie wêreld sy volle betekenis kry en of die Christendom nie mede-verantwoordelik daarvoor is dat die mensheid teen die gebeure geïmmuniseer word nie? Goddank dat ons mag glo dat die suiwer vertolking en die ware verstaan telkens weer die oorhand kry oor teenspraak en verduistering (Berkhof 1973:98).

Juis daarom is 'n poging om ' $n$ eie idioom te soek en te kritiseer in egte teologiebeoefening tog wel op sy plek. Dit sê immers iets oor ons erkenning van menslike onvermoë om die onsêbare te sê. 


\section{SLOTOPMERKING}

Die eg Hervormde teologiese idioom kan in die lig van hierdie beredenering dalk die beste beskryf word as ' $n$ idioom waarin die dialektiese spanning tussen ewigheid en tyd in 'n teologiese spel verwoord word. Daarom wil dié soort teologie nie eindig in 'n afgeremde en geslote sisteem nie, maar dit wil steeds Woordgebonde en tradisiegetrou wees, terwyl dit rekening hou met die eie tyd en omstandighede (Koekemoer 1992:9). Daar word vertel dat Barth tydens die winter-semester van 19611962, wat sy laaste semester as dosent voor sy aftrede was, nie met lesings in die lyn van sy Kerklike Dogmatiek voortgegaan het nie, maar tot almal se verbasing as te ware nuut begin het met 'n reeks lesings onder die titel: 'Evangeliese Teologie: 'n Inleiding'. Miskien moet ons die uniekheid van ons eie teologiese idioom juis hierin soek, dat ons bereid moet wees om altyd weer nuut te begin.

\section{Literatuurverwysings}

Berkhof, H 1973. Christelijk Geloof. Nijkerk: Callenbach. Bonhoeffer, D [1981] 1982. Christologie. Baarn: Ten Have.

Boshoff, P B 1990. Ons teologiese erfenis, Die Hervormer, 1 April 1990, bl 6.

- 1992. 'n Kenmerkend Hervormde teologie. Die Hervormer, 1 November 1992, bl 4.

- 1993. Spanning tussen die behoud van ons kerklike etos en die Kerk se apostolaat. Die Hervomer, 1 Junie 1993, bl 5.

Engelbrecht, B J 1966. Vyftig jaar Dogmatiek: 'n Huldeblyk aan Karl Barth. HTS $22 / 4,62-78$.

Goddefroy, M J 1889. De Kerkkwestie niet een leer-maar een levenskwestie. Tweede druk. Den Haag: De Swart \& Zoon.

Godsey, J D 1963. Karl Barth's table talk. Edinburgh: Oliver \& Boyd.

Haitjema, Th L 1948. Dogmatiek als apologie. Haarlem: De erven.

Koekemoer, J H 1991. Dogmatiek binne konfessionele verband. Professorale intreerede, Universiteit van Pretoria.

- 1992. Dogmatiek en Christelike Etiek binne die Fakulteit Teologie (Afd A) van die Universiteit van Pretoria. HTS 48, 315-328.

Loader, J A 1987. 'Tertium datur' - oor die etiese waarheidsbegrip. HTS 43, 47-57.

- 1989. Ontstaan en eerste periode van Hervormde Teologiese Opleiding aan die Universiteit van Pretoria. HTS 45, 412-437.

Mans, C J 1967. Die lewe en werk van die dogmatikus P J Müller. DD-proefskrif, Universiteit van Pretoria.

Ott, H [1971] 1974. God. Richmond Virginia: John Knox Press. 
Ott, H 1981. Die Antwort des Glaubens. Stuttgart: Kreuz Verlag.

Oberholzer, J P 1993. Die teologiese eie-aardigheid van die Nederduitsch Hervormde Kerk: Vrae en nuanses. HTS 49, 870-886.

Pont, A D 1994. Historiese perspektiewe op die kerklik-teologiese opleiding van die Nederduitsch Hervormde Kerk aan die Universiteit van Pretoria. HTS 50/1, 95-110.

Tracy, D 1981. The analogical imagination. London: SCM Press.

Van Aarde, A G 1992. Eerste treë op die weg na kritiese en historiese NuweTestamentiese wetenskap aan die Universiteit van Pretoria: Die bydrae van J H J A Greyvenstein, hoogleraar 1917-1945. HTS 48, 139-158.

- 1993a. Versoenende verskeidenheid, Die Henormer, 15 September 1993, bl 5.

- 1993b. Mites, metafore en teologie (1), Die Henvormer, 15 Desember 1993, bl $5 \& 8$.

- 1994. Mites metafore en teologie (2), Die Henormer, 15 Januarie 1994, bl 5 \& 6.

Van Niftrik, G C 1948. Een beroerder Israels: Enkele hoofd gedachten in de Theologie van Karl Barth. Nijkerk: Callenbach.

- 1953. Kleine Dogmatiek. Nijkerk: Callenbach.

Van Zyl, F J 1993a. Die stand van teologie in ons kerk in die perspektief van verlede en toekoms, Die Hervormer, 15 September 1993, bl 3.

— 1993b. Die dialektiese teologie, Die Henonner, 15 September 1993, bl 5 \& 6.

- 1993c. Die na-Barthiaanse Teologie, Die Henormer, I Oktober 1993, bl 5 \& 6.

- 1993d. Teologiebeoefening in ons kerk - 'n blik in die hede en die toekoms, Die Henormer, 1 Junie 1993, bl 4 \& 5.

Van Zyl, J 1993. Wat lidmate nie hoor nie. De Kat, Maart 1993, bl 72-75.

Weber, O 1955. Grundlagen der Dogmatik, Erster band. Moers: Neukirchen. 